\title{
PEMODELAN FAKTOR RISIKO PENYAKIT TUBERKULOSIS DI KOTA LHOKSEUMAWE
}

\author{
Novianti", Roslinawati ${ }^{2}$, Siska Desta Roza ${ }^{3}$, Yeffi Masnarivan ${ }^{4 *}$ \\ ${ }_{12.2}$ STIKes Bumi Persada Lhokseumawe Aceh \\ ${ }^{4}$ Fakultas Kesehatan Masyarakat, Universitas Andalas \\ Email: yeffimasnarivan@ph.unand.ac.id
}

Diterima: November 2021, Diterbitkan: Desember 2021

\begin{abstract}
Abstrak
Tuberkulosis (TB) adalah suatu penyakit menular yang disebabkan oleh kuman Mycobacterium tuberculosis. Tuberkulosis merupakan masalah kesehatan yang sampai sekarang menjadi penyakit paling menular dan sangat mematikan di dunia. Kasus TB di Provinsi Aceh pada tahun 2018 ditemukansebanyak 8.471 kasus. Kota Lhokseumawe dengan CNR kasus tuberculosis tertinggi di Provinsi Aceh yaitu 351 per 100.000 penduduk. Tujuan penelitian ini adalah untuk mengetahui model faktor risiko yang mempengaruhi penyakit tuberkulosis di Kota Lhokseumawe.Penelitian ini merupakan studi deskriptif dengan menggunakan analisis data sekunder.Penelitian ini dilakukan di Kota Lhokseumawe pada bulan Maret - September tahun 2021. Penelitian ini menggunakan data sekunder dari BPS Kota Lhokseumawe dan Dinas Kesehatan Kota Lhokseumawe Tahun 2019. Hasil penelitian didapatkan angka prevalensi TB tertinggi yaitu di kecamatan banda sakti sebesar 336 per 100.000penduduk. Sedangkan Kecamatan dengan angka prevalensi TB terendah berada di Kecamatan Muara Dua yaitu 201 per 100.000 penduduk. Terdapat 2 variabel yang secara signifikan membedakan antara dua kluster yaitu variabel persentase rumah tangga yang memiliki lantai tanah dan kepadatan penduduk. Variabel kepadatan penduduk adalah variabel yang paling dominan penyebab penyakit TB di Kota Lhokseumawe.
\end{abstract}

Kata Kunci: Model, Faktor Risiko, Tuberkulosis

\begin{abstract}
Tuberculosis (TB) is an infectious disease caused by the bacterium Mycobacterium tuberculosis. Tuberculosis is a health problem that until now has become the most infectious and very deadly disease in the world. TB cases in Aceh Province in 2018 were found to be 8,471 cases. The city of Lhokseumawe with the highest CNR of tuberculosis cases in Aceh Province was 351 per 100,000 population. The purpose of this study was to determine the model of risk factors that influence tuberculosis in Lhokseumawe City. This research is a descriptive study using secondary data analysis. This research was conducted in Lhokseumawe City in March - September 2021. This study used secondary data from the Lhokseumawe City BPS and Lhokseumawe City Health Office 2019. The results showed that the highest TB prevalence rate was in banda sakti sub-district at 336 per 100,000 population. Meanwhile, the sub-district with the lowest TB prevalence rate is in Muara Dua District, which is 201 per 100,000 population. There are 2 variables that significantly differentiate between the two clusters, namely the proportion of households with a ground floor and population density. The population density variable is the most dominant variable causing TB disease in Lhokseumawe City.
\end{abstract}

Keywords: Model, Risk Factors, Tuberculosis

\section{PENDAHULUAN}

Tuberkulosis (TB) adalah penyakit menular langsung yang disebabkan oleh kuman TB (Mycobacterium Tuberculosis). Sebagian besar kuman TB menyerang paru, tetapi dapat juga mengenai organ tubuh lainnya(Kemenkes RI, 2009).
Tuberkulosis (TB) adalah penyakit menular yang merupakan penyebab utama kesehatan yang buruk, salah satu dari 10 penyebab kematian teratas di dunia dan penyebab utama kematian dari agen infeksi tunggal (peringkat di atas HIV/AIDS). Secara global, diperkirakan 10,0 juta 
(kisaran, 9,0-11,1 juta) orang jatuh sakit TB pada tahun 2018, jumlah yang relatif stabil dalam beberapa tahun terakhir. Beban penyakit sangat bervariasi antar negara, dari kurang dari lima hingga lebih dari 500 kasus baru per 100.000 penduduk per tahun, dengan rata-rata global sekitar 130(World Health Organization, 2019).

Di tingkat global, di tahun 2017 terdapat sekitar 558.000 kasus baru (rentang, 483.000-639.000) TB rifampisin resistan di mana hampir separuhnya ada di tiga negara yaitu India (24\%), China (13\%), dan Rusia (10\%). Di antara kasus TB RR, diperkirakan $82 \%$ kasus tersebut adalah TB MDR. Secara global, 3.6\% kasus TB baru dan $17 \%$ kasus $\mathrm{TB}$ pengobatan ulang merupakan kasus TB MDR/RR(Subdirektorat Tuberkulosis, 2019).

Indonesia merupakan negara ke-2 tertinggi penderita tuberkulosis. Hal tersebut mendorong pengendalian tuberkulosis nasional terus dilakukan dengan intensifikasi, akselerasi, ekstensifikasi dan inovasi program(Kementerian Kesehatan RI, 2020).

Jumlah kasus baru TB di Indonesia sebanyak 420.994 kasus pada tahun 2017 (data per 17 Mei 2018)(Kementerian Kesehatan RI, 2018). Pada tahun 2018 Angka insiden tuberkulosis Indonesia sebesar 316 per 100.000 pendudukdan angka kematian penderita tuberkulosis $\begin{array}{llll}\text { sebesar } \quad 40 \quad \text { per } & 100.000\end{array}$ penduduk(Kementerian Kesehatan RI, 2020).

Di Aceh sendiri, pada tahun 2018 ditemukan jumlah kasus TB sebanyak 8.471 kasus, meningkat 1129 kasus dari tahun sebelumnya yaitu pada tahun 2017 sebanyak 7.342 kasus. Selain itu angka notifikasi semua kasus TB atau Case Notification Rate (CNR) di Aceh berada pada peringkat 26 dari 34 provinsi, yaitu 156 kasus tiap 100.000 penduduk. Istilah CNR itu sendiri adalah jumlah semua kasus tuberkulosis yang diobati dan dilaporkan di antara 100.000 penduduk yang ada di suatu wilayah tertentu(Menawati, 2021).
Kota Lhokseumawe merupakan kabupaten/kota dengan CNR semua kasus tuberkulosistertinggi nomor dua setelah Banda Aceh yaitu 289 per 100.000 penduduk pada tahun 2019 (Dinas Kesehatan Aceh, 2019).

Adanya karakteristik yang berbeda pada penderita TB seperti keadaan ekonomi, faktor sosialbudaya, demografi dan keadaan geografis pada tiap wilayah di Kota Lhokseumawe akanmenyebabkan kualitas kesehatan dan beban masalah yang berbeda pula, sehingga untukoptimalisasi program pemberantasan TB dibutuhkan strategi yang tepat untuk mengatasi haltersebut, yakni salah satunya melalui metode pengelompokkan daerah di Kota Lhokseumaweyang mempunyai karakteristik tertentu berdasarkan faktor penyebab TB yang dimiliki daerahtersebut.

Tujuan penelitian ini adalah untuk mengetahui model faktor risiko yang mempengaruhi penyakit tuberkulosis di Kota Lhokseumawe

\section{METODEPENELITIAN}

Penelitian ini merupakan studi deskriptif analitik dengan menggunakan data sekunder dan analisis multivariat meliputi analisis kluster, analisis biplot dan analisis diskriminan.Unit analisis dalam penelitian ini adalah seluruh kecamatan yang ada di Kota Lhokseumawe dan menggunakan faktor penyebab TB Paru di Kota Lhokseumawe. Penelitian ini dilakukan di Kota Lhokseumawe pada bulan Maret - Oktober tahun 2021.

Variabel yang digunakan dalam penelitian ini terdiri dari dua belas variabel atau atribut, sebagaiberikut: Prevalensi Tuberkulosis, persentase cakupan bayiyang mendapat imunisasi BCG, jumlahposyandu, persentase penduduk miskin, persentase sumber air minum layak, tidak ada dan tidak menggunakan fasilitas tempat BAB, nilai indeks kualitas udara (IKU), RT memiliki lantai tanah, kepadatan penduduk, jumlah balita gizi kurang, bahan bakar utama memasak dengan kayu, dan rumah tangga sanitasi 
layak.

HASIL DAN PEMBAHASAN

Gambaran Kasus TB di Lhokseumawe

Berikut jumlah kasus TB berdasarkan Kecamatan di Kota Lhokseumawe tahun 2019.

Tabel 1. Distribusi Kasus TB

Berdasarkan Kecamatan di Kota

Lhokseumawe tahun 2019

\begin{tabular}{lccc}
\hline Kecamatan & $\begin{array}{c}\text { Jumlah } \\
\text { Penduduk }\end{array}$ & $\begin{array}{c}\text { Jumlah } \\
\text { TB }\end{array}$ & $\begin{array}{c}\text { Prevalensi } \\
\text { TB (/100.000) }\end{array}$ \\
\hline Kec. Blang Mangat & 29.968 & 98 & 327 \\
\hline Kec. Banda Sakti & 84.496 & 284 & 336 \\
\hline Kec. Muara Satu & 32.963 & 102 & 309 \\
\hline Kec. Muara Dua & 56.775 & 114 & 201 \\
\hline Total & $\mathbf{2 0 4 . 2 0 2}$ & $\mathbf{5 9 8}$ & $\mathbf{1 1 7 3}$ \\
\hline Sumber : Dinas Kesehatan Kota Lhokseumawe
\end{tabular}

Berdasarkan tabel 1 diatas, jumlah penderita TB terbanyak terdapat di Kecamatan Banda Saktiyaitu berjumlah 284kasus. Begitu juga dengan angka prevalensi tertinggi yaitu di kecamatan banda sakti sebesar 336 per 100.000 penduduk. Sedangkan Kecamatandengan angka prevalensiTB terendah berada di Kecamatan Muara Dua yaitu 201 per 100.000 penduduk.

Berikut gambaran variabel yang mempengaruhi kejadian TB berdasarkan Kecamatan yang dibagi kedalam dua faktor yaitu faktor kesehatan dan sosial ekonomi demografi.

Tabel 2. Faktor Kesehatan yang Mempengaruhi Penyakit TB di Kota Lhokseumawe

\begin{tabular}{|c|c|c|c|c|c|c|c|c|c|c|}
\hline Kecamatan & $\begin{array}{c}\text { Prevale } \\
\text { nsi TB }\end{array}$ & $\begin{array}{c}\text { Cakupan } \\
\text { Bayi } \\
\text { Imunisasi } \\
\text { BCG }(\%)\end{array}$ & $\begin{array}{l}\text { Jumlah } \\
\text { Posyandu }\end{array}$ & $\begin{array}{l}\text { Sumber } \\
\text { Air Minum } \\
\text { Layak (\%) }\end{array}$ & $\begin{array}{c}\text { Tidak Ada dan } \\
\text { Tidak } \\
\text { Menggunakan } \\
\text { Fasilitas Tempat } \\
\text { BAB (\%) }\end{array}$ & $\begin{array}{c}\text { Nilai } \\
\text { Indeks } \\
\text { Kualitas } \\
\text { Udara } \\
\text { (IKU) }\end{array}$ & $\begin{array}{c}\text { \% RT } \\
\text { Memiliki } \\
\text { Lantai } \\
\text { Tanah }\end{array}$ & $\begin{array}{c}\text { Jumlah } \\
\text { Balita } \\
\text { Gizi } \\
\text { Kurang }\end{array}$ & $\begin{array}{c}\text { \% Bahan } \\
\text { Bakar } \\
\text { Utama } \\
\text { Memasak } \\
\text { dengan Kayu }\end{array}$ & $\begin{array}{c}\% \\
\text { Rumah } \\
\text { Tangga } \\
\text { Sanitasi } \\
\text { Layak }\end{array}$ \\
\hline Kec. Blang Mangat & 327 & 67,3 & 23 & 85,6 & 8,49 & 89,35 & 1,17 & 98 & 20,14 & 76,3 \\
\hline Kec. Banda Sakti & 336 & 68,5 & 29 & 87,1 & 12,01 & 94,25 & 9,70 & 120 & 18,58 & 84,3 \\
\hline Kec. Muara Satu & 309 & 71,3 & 12 & 89,1 & 10,20 & 90,87 & 0,40 & 110 & 13,23 & 80,1 \\
\hline Kec. Muara Dua & 201 & 60,5 & 21 & 91,2 & 6,34 & 91,17 & 1,86 & 102 & 11,58 & 95,7 \\
\hline Jumlah & 1173 & 267,60 & 85,00 & 353,02 & 37,04 & 365,64 & 13,13 & 430,00 & 63,53 & 336,40 \\
\hline
\end{tabular}

Sumber : Dinas Kesehatan Kota Lhokseumawe

Berdasarkan tabel 2, didapatkan permasalahan kesehatan pada masingmasing Kecamatan di Kota Lhokseumawe. Kecamatan Blang Mangat bermasalah pada tingginya persentase bahan bakar utama memasak dengan kayu dan rendahnya persentase rumah tangga bersanitasi layak. Kecamatan Banda Sakti bermasalah pada tingginya angka prevalensi $\mathrm{TB}$, tinginya persentase tidak ada dan tidak menggunakan fasilitas tempat BAB, tingginya persentase RT memiliki lantai tanah, dan tingginya jumlah balita gizi kurang. Kecamatan Muara Satu bermasalah pada rendahnya jumlah posyandu aktif. Kecamatan Muara Dua bermasalah pada rendahnya cakupan bayi imunisasi BCG.

Dengan diketahuinya permasalah kesehatan pada masing-masing Kecamatan di Kota Lhokseumawe maka dalam upaya pencegahan dan penanggulangan TB bisa terfokus terhadap apa yang menjadi permasalahan pada masing-masing Kecamatan tersebut.
Kecamatan Blang Mangat upaya yang harus dilakukan adalah menurunkan persentase bahan bakar utama memasak dengan kayu dan meningkatkan persentase rumah tangga bersanitasi layak. Kecamatan Banda Sakti upaya yang harus dilakukan adalah menurunkan angka prevalensi TB, menurunkan persentase tidak ada dan tidak menggunakan fasilitas tempat BAB, menurunkan persentase RT memiliki lantai tanah, dan mengurangi jumlah balita gizi kurang. Kecamatan Muara Satu upaya yang harus dilakukan adalah meningkatkan jumlah posyandu aktif. Kecamatan Muara Dua upaya yang harus dilakukan adalah meningkatkan cakupan bayi imunisasi BCG.

Kecamatan yang memiliki masalah kesehatan terbanyak berdasarkan hasil deskriptif faktor kesehatan adalah Kecamatan Banda Sakti dan Kecamatan Blang Mangat. Kecamatan Banda Sakti masuk kedalam kluster kedua sedangkan Kecamatan Blang Mangat masuk pada 
kluster pertama. Hal tersebut mengindikasikan tidak terdapat ketertarikan spasial untuk faktor kesehatan pada wilayah-wilayah tersebut karena bukan disebabkan oleh letak yang saling berdekatan.

Dalam era otonomi daerah, pemberdayaan dan kemandirian merupakan salah satu strategi dalam pembangunan kesehatan. Artinya bahwa setiap orang-orang dan masyarakat bersama-sama pemerintah berperan, berkewajiban, dan bertanggung jawab untuk memelihara dan meningkatkan derajad kesehatan perorangan, keluarga, masyarakat beserta lingkungannya. Peran petugas kesehatan sangtlah penting karena merupakan salah satu sumber daya kesehatan yang ada di masyarakat perlu memberikan manifestasi agar program PHBS bisa berjalan (Masnarivan, 2021)

\begin{tabular}{lcc}
$\begin{array}{c}\text { Tabel } 3 \text { Faktor Sosial Ekonomi dan } \\
\text { Demografi yang Mempengaruhi }\end{array}$ \\
$\begin{array}{l}\text { Penyakit TB di Kota Lhokseumawe } \\
\text { Kabupaten/Kota }\end{array}$ & $\begin{array}{c}\text { Kepadatan } \\
\text { Penduduk/km }\end{array}$ & $\begin{array}{c}\text { \% Penduduk } \\
\text { Miskin }\end{array}$ \\
\hline \multicolumn{1}{c}{$\mathbf{1}$} & $\mathbf{2}$ & $\mathbf{3}$ \\
\hline Kec. Blang Mangat & 374,9 & 6,65 \\
\hline Kec. Banda Sakti & 6.512 & 6,26 \\
\hline Kec. Muara Satu & 484,2 & 7,16 \\
\hline Kec. Muara Dua & 626,1 & 7,05 \\
\hline Rata-rata & 1999,30 & 6,78 \\
\hline
\end{tabular}

Sumber : BPS Kota Lhokseumawe

Berdasarkan tabel 3, Kecamatan yang memiliki masalahtingginya angka kepadatan penduduk paling banyak dialamioleh Kecamatan Banda Sakti. Sedangkan Kecamatan Muara Satubermasalah pada tingginya pesentase penduduk miskin.

Kepadatan penduduk merupakan salah satu faktor yang berkaitan dengan lingkungan sosial yang sangat berpengaruh terhadap status kesehatan fisik dan mental, baik secara individu maupun kelompok karena penduduk yang padat akan mempermudah dalam penyebaran penyakit. (Gubler, 1998) Untuk menanggulangi kepadatan penduduk pada Kota di Kota Lhokseumawe perlu adanya peningkatkan pelayanan kesehatan dan kemudahan dalam menjadi akseptor Keluarga Berencana (KB) sehingga pertambahan jumlah penduduk dapat diminimalisir.

\section{Analisis Klaster}

Berikut hasil analisis kluster Kecamatan berdasarkan faktor penyebab penyakit TB di Kota Lhokseumawe.

Tabel 4 Anggota Kelompok (clustermembership) Hasil Analisis

\begin{tabular}{|c|c|}
\hline Anggota Cluster & 1 \\
\hline Kabupaten/Kota & 2 Clusters \\
\hline Kec. Blang Mangat & 1 \\
\hline Kec. Banda Sakti & 2 \\
\hline Kec. Muara Satu & 11 \\
\hline Kec. Muara Dua & 11 \\
\hline
\end{tabular}

Tabel 4 merupakan output rincian jumlah cluster dengan anggota yang terbentuk. Berdasarkan tabel diatas, akan dipilih dua kelompok cluster.

Penentuan jumlah kelompok menjadi dua, tiga atau empat kluster berdasarkan output dendogram yang dihasilkan, dendogram tersebut menggambarkan bahwa dua kelompok memiliki komposisi yang lebih optimal karena tiga kelompok terlalu kecil. Hasil penelitian ini berbeda dengan penelitian Agustina dan penelitian Puti Aulia bahwa Kecamatan yang ada di Kota Surabaya dan di Kota Padang dikelompokkan menjadi 3 kluster menggunakan metode ward. (Aulia, 2014)(Agustina, 2014)

Berikut hasil pengelompokan Kecamatan yang terbentuk berdasarkan faktor penyebab penyakit TB di Kota Lhokseumawe.

Tabel 5 Hasil Pengelompokan Kecamatan di Kota Lhokseumawe

\begin{tabular}{cl}
\hline \multicolumn{1}{c}{ Kluster } & \multicolumn{1}{c}{ Kabupaten/Kota } \\
\hline (1) & \multicolumn{1}{c}{$(\mathbf{2})$} \\
\hline Kluster 1 & Kecamatan Blang Mangat \\
& Kecamatan Muara Satu \\
& Kecamatan Muara Dua \\
\hline Kluster 2 & Kecamatan Banda Sakti \\
\hline
\end{tabular}

\section{Analisis Diskriminan}

Berikut hasil pengelompokankecamatan di Kota Lhokseumawe Berdasarkan Faktor Penyebab TBMenggunakan Analisis 
Diskriminan:

Tabel 6 Skor Mean Variabel Berdasarkan Kluster

\begin{tabular}{lcc}
\hline \multicolumn{1}{c}{ Variabel } & \multicolumn{2}{c}{$\begin{array}{c}\text { Skor Rata-Rata } \\
\text { Kelompok }\end{array}$} \\
\hline \multicolumn{1}{c}{$(\mathbf{1 )}$} & $\mathbf{( 1 )}$ & $\mathbf{( 2 )}$ \\
\hline Prevalensi TB (X1) & 0,17 & $\mathbf{- 0 , 5 0}$ \\
Persentase Cakupan Bayi Imunisasi & $-0,12$ & $\mathbf{0 , 3 5}$ \\
BCG (X2) & $-0,37$ & $\mathbf{1 , 1 0}$ \\
Jumlah Posyandu (X3) & 0,42 & $\mathbf{- 1 , 2 7}$ \\
Persentase Penduduk Miskin(X4) & 0,16 & $\mathbf{- 0 , 4 7}$ \\
Persentase Sumber Air Minum Layak & & \\
(X5) & $-0,38$ & $\mathbf{1 , 1 4}$ \\
Persentase Tidak Ada dan Tidak & & \\
Menggunakan Fasilitas Tempat BAB & & \\
(X6) & $-0,46$ & $\mathbf{1 , 3 8}$ \\
Nilai Indeks Kualitas Udara (X7) & $-0,50$ & $\mathbf{1 , 4 9}$ \\
Persentase Rumah Tangga Memiliki & & \\
Lantai Tanah (X8) & $-0,50$ & $\mathbf{1 , 5 0}$ \\
Kepadatan Penduduk (X9) & $-0,43$ & $\mathbf{1 , 2 9}$ \\
Jumlah Balita Gizi Kurang (X10) & $-0,22$ & $\mathbf{0 , 6 5}$ \\
Persentase Bahan Bakar Utama & & \\
Memasak dengan Kayu(X11) & $-0,01$ & $\mathbf{0 , 0 2}$ \\
Persentase Rumah Tangga Sanitasi & & \\
Layak (X12) & &
\end{tabular}

Tabel 6 merupakan nilai mean yang didapatkan untuk setiap variabel berdasarkan kluster kabupaten, untuk klaster 1 tidak memiliki permasalahan terhadap faktor penyebab TB jika dibandingkan klaster dua. Berdasarkan tabel diatas, terlihat perbedaan rata-rata pada masing-masing kluster berdasarkan skor mean untuk setiap variabel.

Tabel 7 Uji Kesetaraan Mean Group

\begin{tabular}{lcc}
\hline \multicolumn{1}{c}{ Variabel } & $\begin{array}{c}\text { Wilks' } \\
\text { Lambda }\end{array}$ & F Test Sig \\
\hline Prevalensi TB (X1) & 0,89 & 0,669 \\
\hline Persentase Cakupan Bayi Imunisasi BCG (X2) & 0,946 & 0,767 \\
\hline Jumlah Posyandu (X3) & 0,462 & 0,266 \\
\hline Persentase Penduduk Miskin (X4) & 0,286 & 0,155 \\
\hline Persentase Sumber Air Minum Layak (X5) & 0,901 & 0,685 \\
\hline $\begin{array}{l}\text { Persentase Tidak Ada dan Tidak Menggunakan } \\
\text { Fasilitas Tempat BAB (X6) }\end{array}$ & 0,426 & 0,242 \\
\hline Nilai Indeks Kualitas Udara (X7) & 0,15 & 0,078 \\
\hline $\begin{array}{l}\text { Persentase Rumah Tangga Memiliki Lantai } \\
\text { Tanah (X8) }\end{array}$ & 0,019 & $\mathbf{0 , 0 1}$ \\
\hline Kepadatan Penduduk (X9) & 0,001 & $\mathbf{0 , 0 0 1}$ \\
\hline Jumlah Balita Gizi Kurang (X10) & 0,264 & 0,142 \\
\hline $\begin{array}{l}\text { Persentase Bahan Bakar Utama Memasak } \\
\text { dengan Kayu (X11) }\end{array}$ & 0,81 & 0,564 \\
\hline $\begin{array}{l}\text { Persentase Rumah Tangga Sanitasi Layak (X12) } \\
\text { (n) }\end{array}$ & 1,00 & 0,984 \\
\hline
\end{tabular}

Tabel 7 merupakan output dari dua uji statistik yaitu wilk's lamda dan F test, berdasarkan kedua uji tersebut teridentifikasi 2 variabel yang secara signifikan membedakan antara kedua kluster dan akan dimasukkan (entered) ke dalam persamaan diskriminan yaitu variabel persentase rumah tangga yang memiliki lantai tanah dan kepadatan penduduk.

Tabel 8 Derajat Hubungan antara Hasil Diskriminan dan Kluster Kecamatan di Kota Lhokseumawe

\begin{tabular}{llclcc}
\hline Fungsi & $\begin{array}{c}\text { \% of } \\
\text { Variance }\end{array}$ & $\begin{array}{c}\text { Cumulat } \\
\text { ive } \%\end{array}$ & Chi-square & p value & $\begin{array}{c}\text { Canonic } \\
\text { al } \\
\text { Correlat } \\
\text { ion }\end{array}$ \\
\hline 1 & 100 & 100 & 9,84 & 0,007 & 1,00 \\
\hline
\end{tabular}

Tabel 8 merupakan hasil dari pengukuran derajat hubungan antara skor hasil diskriminan dan kluster kecamatanatau besarnya variabilitas yang mampu diterangkan oleh variabel independen terhadap kluster kecamatan yang terbentuk. Berdasarkan hasil tersebut, diperoleh nilai percent of variance sebesar atau setara dengan $100 \%$, artinya keseluruhan dari kluster kecamatan dapat dijelaskan oleh 1 fungsi modeldiskriminan yang terbentuk karena kedua fungsi tersebut merupakan ringkasan dari seluruh variabel independen, kemudian nilai signifikan chi-square sebesar 0,007 $(<0.05)$; artinya, ada perbedaan yang signifikan pada tiap kluster kecamatan berdasarkan model diskriminan.Dari tabel juga diperoleh bahwa nilai canonical correlation sebesar 1,00 untuk fungsi 1 dan bila dikuadratkan menjadi 100 ; artinya $100 \%$ varians dari variabel dependen dapat dijelaskan dari model diskriminan yang terbentuk.

\section{Tabel 9 Koefisien Fungsi Diskriminan}

\begin{tabular}{lc}
\hline \multicolumn{1}{c}{ Variabel } & Fungsi 1 \\
\hline $\begin{array}{l}\text { Persentase Sumber Air Minum } \\
\text { Layak (X5) }\end{array}$ & $-4,51$ \\
\hline Kepadatan Penduduk (X9) & 4,62 \\
\hline
\end{tabular}

Tabel 9 merupakan nilai koefisien yang menerangkan fungsi diskriminan, yaitu dari satu fungsi yang terbentuk, cukup satu fungsi yang digunakan untuk menerangkan kedua variabel yang paling dominan seperti penjelasan pada tabel 6 . Tabel diatas juga menerangkan bahwa variabel kepadatan pendudukadalah 
variabel yang paling dominan berdasarkan besar nilai yang terbentuk tanpa memperhatikan tanda positif atau negatif.

Tabel 10 Hasil Uji Ketepatan Pengelompokan

\begin{tabular}{|c|c|c|c|c|c|}
\hline \multirow[t]{2}{*}{ Variabel } & \multirow{2}{*}{\multicolumn{2}{|c|}{ Kluster }} & \multicolumn{2}{|c|}{$\begin{array}{l}\text { Prediksi Anggota } \\
\text { Kelompok }\end{array}$} & \multirow[b]{2}{*}{2 Total } \\
\hline & & & Kluster 1 & Kluster 2 & \\
\hline \multirow{4}{*}{ Original } & \multirow{2}{*}{ Count } & 1 & 3 & 0 & 3 \\
\hline & & 2 & 0 & 1 & 1 \\
\hline & \multirow{2}{*}{$\%$} & 1 & 100,0 &, 0 & 100,0 \\
\hline & & 2 &, 0 & 100,0 & 100,0 \\
\hline
\end{tabular}

Tabel 10 merupakan hasil akhir dari analisis diskriminan yaitu uji ketepatan pengelompokan, berdasarkan hasil uji tersebut diperoleh tingkat ketepatan fungsi pengelompokan sempurna yaitu mencapai $100 \%$. Dengan demikian fungsi diskriminan yang dihasilkan memberikan tingkat ketepatan yang tinggi dan dapat digunakan sebagai fungsi yang membedakan Kecamatan berdasarkan penyebab penyakit TB di Kota Lhokseumawe.

\section{SIMPULAN}

Angka prevalensi TB tertinggi pada kecamatan di Kota Lhokseumawe yaitu di kecamatan banda sakti sebesar 336 per 100.000 penduduk. Sedangkan Kecamatan dengan angka prevalensi TB terendah berada di Kecamatan Muara Dua yaitu 201 per 100.000 penduduk. Terdapat 2 variabel yang secara signifikan membedakan antara dua kluster yaitu variabel persentase rumah tangga yang memiliki lantai tanah dan kepadatan penduduk. Variabel kepadatan penduduk adalah variabel yang paling dominan penyebab penyakit TB di Kota Lhokseumawe

\section{UCAPAN TERIMAKASIH}

Ucapan terima kasih kepada RistekBRIN yang telah memberikan bantuan dana dalam Skim Penelitian Dosen Pemula, serta STIKes Bumi Persada Lhokseumawe yang telah menfasilitasi dan mendukung penelitian ini.

\section{DAFTAR PUSTAKA}

Agustina, G. Z. (2014) Pemetaan Penyakit
Tuberkulosis di Kota Surabaya Tahun 2012, Analisis Statistik Multivariat.

Aulia, P. (2014) Analisis Pengelompokan dan Pemetaaan Kecamatan Berdasarkan Faktor Penyebab Penyakit Tuberkulosis (TB) Paru di Kota Padang tahun 2014. Universitas Andalas.

Dinas Kesehatan Aceh (2019) Profil Kesehatan Aceh.

Gubler (1998) 'Dengue haemorrhagic fever; A global up date dengue', Departement of Health and Human Services, p. Vol. 14.
Kemenkes RI (2009) PEDOMAN PENANGGULANGAN TUBERKULOSIS (TB).

Kementerian Kesehatan RI (2018) 'InfoDatin Tuberculosis', Kementerian Kesehatan $R I, \quad$ p. $1 . \quad$ Available at: https://www.depkes.go.id/article/view/1 8030500005/waspadai-peningkatanpenyakitmenular.html\%0Ahttp://www.depkes.go .id/article/view/17070700004/programindonesia-sehat-dengan-pendekatankeluarga.html.

Kementerian Kesehatan RI (2020) Profil Kesehatan Indonesia Tahun 2019. Jakarta. doi: 10.5005/jp/books/11257 5 .

Masnarivan, Y. (2021) Memahami Penyakit Demam Berdarah Dengue Di Sumatera. Yogyakarta: Bintang Pustaka Madani.

Menawati, T. (2021) Menyikapi Tuberkulosis di Tengah Pandemi, https://aceh.tribunnews.com/. Available at:

https://aceh.tribunnews.com/2021/03/27/ menyikapi-tuberkulosis-di-tengahpandemi (Accessed: 11 November 2021).

Subdirektorat Tuberkulosis (2019) Situasi TBC di Indonesia, https://tbindonesia.or.id/. Available

at: https://tbindonesia.or.id/informasi/tentan g-tbc/situasi-tbc-di-indonesia-2/ (Accessed: 5 April 2021).

World Health Organization (2019) Global Tuberculosis Report 2019. 